\title{
P2P: Assessing a Peer Evaluation Strategy
}

\author{
Ching-Wen Chang \\ Cathy J. Pearman \\ Missouri State University \\ Nicholas W. Farha \\ Logan University
}

\begin{abstract}
The purpose of this study was to determine the effectiveness of peer evaluation in a performance-based, Web-enhanced undergraduate instructional technology course. The results of a survey administered at the end of three semesters indicated that learners believe the peer evaluation process helped them improve the quality of their own work, both as a result of being a peer evaluator themselves and from the quality of the feedback received from their classmate-evaluators. Higher quality final projects with fewer mistakes corroborated the students' assessment. These findings provide valuable information for instructors who are currently utilizing or considering the implementation of a peer evaluation process as a part of their instructional strategy. The results of this study indicate that including peer evaluation in the final project enhanced student performance. Significant technology integration was used to facilitate the projects.
\end{abstract}

Keywords: peer evaluation, peer assessment, instructional strategies, collaboration, team-based learning

\section{Introduction}

The primary goal of an instructor is to facilitate student learning. Educators spend a significant amount of time developing different instructional strategies in the hope these strategies will enhance learning, improve outcomes and make the learning process more relevant. Research has showed active student engagement in the learning process enhances knowledge acquisition and retention. Use of classroom strategies which encourage student involvement and interaction with one another can facilitate higher learning outcomes (Todd $\&$ Hudson, 2007).
One such strategy is through the use of peer evaluation. Peer evaluation can be defined as the process of checking another's work against the requirements that have been given, and providing constructive feedback (Seymour Community Schools, $\llbracket 16,2009)$. As will be delineated in more detail in the literature review that follows, there appears to be a consensus among educators that peer evaluation has a number of pedagogical benefits. These benefits include enhanced student learning, improved quality of work, and increased ability to provide effective feedback, to name a few (Rubin, 2006). 
In this research study, students were required to evaluate one of their classmate's projects. Before submitting their class project in its final form, the students were asked to post their projects in Blackboard ${ }^{\mathrm{TM}}$ and include questions for a peer evaluator to use such as, Could you check if all my links are working properly?, Is the language I used in my project easy enough for a $2^{\text {nd }}$ grader to understand?, Does my design follow visual literacy guidelines?, and so forth. Each student chose one classmate's project to review. The requirements of this peer evaluation (Appendix B) process included (a) providing constructive and professional feedback by answering all the questions that were posted, (b) pointing out mistakes and/or missing requirements from the rubric (Appendix C), and (c) making any other comments the peer reviewer believed would be helpful to their classmate. From this process, the students would be made aware of errors and omissions from the rubric they might not discover on their own. The goal was to give the student an opportunity to make corrections and determine rubric adherence prior to final submission of their projects. Number of errors and quality of projects was used as a comparison between prior projects completed in this class without peer evaluators and current projects with peer evaluators in order to determine if peer evaluation was a useful instructional strategy.

\subsection{Technology Integration}

The project itself involved computer-based instruction (CBI). The students were to create a CBI lesson using PowerPoint that reflected a lesson in their subject area and the grade level that they will be teaching in the future. Besides using computer-based instruction, other technology integration was infused in the project. For example, the final project for the course was initially explained in class using SMART Board ${ }^{\mathrm{TM}}$ technology. A complete overview of the project was delineated including samples of previous projects. Via SMART Board, the students could see examples of projects that met all the requirements in the rubric. This technology also allowed the students to see a demonstration of Kiosk Mode in PowerPoint, with embedded video, audio clips, and documents. The SMART technology allowed the students to conceptualize a multimedia project.

A part of the project included embedding video clip. The technology used for this portion is Movie Maker ${ }^{\mathrm{TM}}$ and Photo Story ${ }^{\mathrm{TM}}$. Proficiency with these software applications was a required part of earlier assignments. Embedding the technology into the final project was one of the requirements. Embedding a document - a .pdf file, MS Word document or MS Publisher file - was also required for their CBI lesson.

The students were required to post their draft projects to the Blackboard Discussion Board in order for their classmates to provide feedback. Proficiency with this feature of the course management system was required (part of the rubric) to complete the project. At the beginning of the semester, the entire class participates in a Blackboard orientation workshop as part of the course.

\subsection{Purpose of the Study}

Based upon the evidence shown from lower scores on projects in previous semesters, it is apparent some students have trouble following rubrics and/or requirements for their projects. Whether they do not understand how, do not take the time, or simply are not motivated, the result is the same - less than adequate work. Students often become frustrated because they lose points on their projects due to obvious, easily correctable mistakes and/or omissions. 
At the same time, instructors often become frustrated because they cannot understand why students did not follow the requirements even with a written rubric in hand. Could a peer evaluation strategy mitigate this situation? The current study attempted to answer this question by ascertaining the effectiveness of a peer evaluation assignment over a three semester period. The technology integration described above was utilized (required) in all sections of all classes throughout this research project.

\subsection{Research Questions}

The goal of this study is to determine if using peer evaluation as a part of the course requirements reinforces the rubric and motivates students to follow the rubric more closely while they work on their projects. Peer evaluation also gives the students an additional opportunity to align their own projects with rubrics while reviewing their peers' projects. As mentioned, part of the requirements for this peer evaluation was to provide constructive and professional responses to the classmate whose work they reviewed via the technology provided. This process generated three research questions for the study:

1. Does the peer evaluation process improve the quality (result in overall higher scores on the projects) of learning outcomes?

2. Does the method of selection of the peer-evaluator make a difference?

3. Does the quality of the peer feedback improve learning outcomes?

\section{Literature Review}

Teaching and learning are dynamic interactions constantly occurring between students and instructors and among students themselves. Students should be involved in the learning process and take responsibility for their learning. Quarrie (2007) addresses the need "...to improve teaching methods in order to actively involve students in the teaching process, help them learn more effectively, and reduce the low exam pass rate" and suggests that educators "...test students' ability to assess themselves and each other by introducing student peer reviewing [italics added] and student self-assessment exercises" (p. 203).

The peer evaluation process provides the opportunity for students to learn from peers and apply what they have learned in real practice. Peer evaluation is also a learning activity that involves sharing experience and knowledge through collaboration and group participation while learning from peers. Margaryan (2008) states peer evaluation is valid and practical as a means of "enhancing knowledge sharing and peer learning within and across the subject disciplines, as well as in terms of enabling contextualised professional development" $(\llbracket 3)$.

Every professional educator has concerns when they first adopt a new instructional methodology or teaching strategy. In this particular case, these concerns included uncertainty about the students' ability to provide helpful feedback, students' time management skills, and their reaction to feedback from peers. Work by Rubin (2006), addressing faculty concerns about the journal review process, found that “....research support for peer feedback suggests that students build skills in the process, gain knowledge of the required level of work, increase their level of responsibility, and facilitate their own learning effectively" (p. 384).

Rubin (2006) also states that peer evaluation not only improves student ability to receive constructive feedback, but also demonstrates the utilization of this feedback on performance 
improvement across a variety of assignments, both individual and group. Overall, Rubin (2006) found that when faculty share the responsibility for providing feedback by requiring peer evaluation, student learning is enhanced, the project quality is improved, and students increase their ability to provide useful feedback.

Several studies (Falchikov \& Goldfinch, 2000; Macpherson, 1999) indicate that when sufficient practice and clear instructions are provided, students can conduct peer feedback that is congruent with faculty member's feedback. Ozogul, Olina, and Sullivan (2008) explored the use of multiple sources of evaluators for student projects. The participants were pre-service teachers (as in the current study) and the researchers found that feedback from any of three evaluator types, teacher, self, or peer, significantly improved the final form of the assignment. Similarly, Somervell (1993) studied alternatives to traditional evaluation methods including peer evaluation, and found that peer evaluation promotes a studentcentered, process-oriented approach.

Moreover, Todd and Hudson (2007), while studying the efficacy of a peer evaluation assignment in a public relations course, reported

This peer-evaluation assignment encouraged students to think critically, synthesize information and write about public relations course material rather than incorporate surface information into written assignments. Because peer reviewers can improve the grades on their final papers by offering concrete suggestions to the original authors, students tended to report that the peerevaluation process improved their writing skills, critical thinking ability, and their public relations concepts and theories. This research demonstrates how peer evaluation can be a positive learning exercise that prompts students to develop higher-order cognitive skills and to improve their writing skills while learning discipline-specific course concepts. (p. 30)

Peer evaluation is not without its critics (see e.g., Root, 1987; Weeks, 1990). Crooks (1988) found that some evaluation practices can act to reduce levels of interest in the students' ongoing work. Cheng and Warren (1997), studying the use of peer assessment in English language programs, found that students were less than positive about assessing their peers' language proficiency.

Overall, however, most studies (Ballantyne et al., 2002; Topping, 1998) agree that what students can gain from the peer evaluation process far outweighs any disadvantages. Brown (1998) says the advantages of peer evaluation include increasing motivation of students to learn, taking the responsibility for their own learning, making evaluation a part of learning, and considering mistakes not as failures but as opportunities for re-learning.

\section{Methodology}

\subsection{Participants}

This research was essentially a pilot study in that this was the first time peer evaluations were implemented in this performancebased, Web-enhanced undergraduate course in instructional technology. Convenience sampling was utilized for this study because participant availability was a function of class enrollment. Thus, all 56 participants were undergraduate pre-service teachers in a required instructional technology applications course at a Midwest public university. Participation in the study was totally voluntary, 
had no affect upon grades, and no extra credit was offered for participation.

There were 45 females and 11 males who completed the survey. Forty-one of the participants were traditionally aged college students between the ages of $18-22$, nine of the participants were 23-30, and six were between 31-40+ years old. The survey respondents' academic standing was: no first-year; 12 sophomores; 25 juniors; 18 seniors; and 1 postbachelor. Table 1 summarizes this demographic information.

Table 1. Descriptive analysis of demographics information

\begin{tabular}{|c|c|c|}
\hline \multirow{3}{*}{ Gender } & & Percent \\
\hline & Male & 19.6 \\
\hline & Female & 80.4 \\
\hline \multirow[t]{4}{*}{$\overline{\text { Age }}$} & $18-22$ & 73.2 \\
\hline & $23-30$ & 16.1 \\
\hline & $31-39$ & 8.9 \\
\hline & $40+$ & 1.8 \\
\hline \multirow[t]{5}{*}{ Status } & First year & 0.0 \\
\hline & Sophomore & 21.4 \\
\hline & Junior & 44.6 \\
\hline & Senior & 32.1 \\
\hline & Post Bachelor & 1.8 \\
\hline
\end{tabular}

\subsection{Research Design and Instrument}

This study utilized a survey design, a preexperimental, descriptive research method. In survey designs the "focus is directed more toward learning about a population and less on relating variables" (Creswell, 2005, p. 354) which accommodated the intent of this study well. The survey design "...consists of two elements - a single instance of a causal event and the assessment of its effects" (Cherulnik, 1983, p. 158). Figure 1 illustrates this research design based upon the notation ( $\mathrm{X}=$ intervention, $\mathrm{O}=$ observation) developed by Campbell and Stanley (1966).

$$
\text { X } \quad \mathrm{O}
$$

Figure 1. The posttest only pre-experimental design
A cross-sectional survey instrument (found in its entirety in Appendix A) was developed by these researchers. The original intent of this study was to attempt to determine the efficacy of a peer evaluation strategy for this college course. Thus, the three research questions were developed. These questions formed the basis for the survey instrument (Appendix A). A cross-sectional survey gathers data on a sample population at a single point in time and "examines current practices" (Creswell, 2005, p. 356) which was precisely the researchers' goal.

\subsection{Procedures and Data Collection}

Approval for this project was obtained from the Institutional Review Board in February of 2009 (Approval \#09281). Data gathering took place the last week of classes during the Spring 
2009, Fall 2009, and Spring 2010 semesters. Three sections of the course were asked to participate in each of the three semesters. The first semester, the participants received a paperand-pencil survey from a teaching assistant during the last class period.

After the first semester, the survey was digitized into a Web-based form. The technology utilized to deliver the survey was inQsit ${ }^{\mathrm{TM}}$, an online assessment instrument. The inQsit site housing the survey was accessed via a link in Blackboard. This technology-based delivery method has been used exclusively since the first semester.

Participation in the study entailed completing either the written survey (first semester only) or the online survey which took approximately 5-10 minutes. Consent to participate in the study was obtained prior to taking the survey (in either format) and participation was voluntary and anonymous. The data collected was used in aggregate so individual participants could not be identified.

\subsection{Limitation of the Study}

The following factor is a limitation to this study that could inhibit the results of the research results:

The findings of this study on the effectiveness of peer evaluation may not necessarily generalize to some educational environments or populations due to the limited sample, size making it more difficult to determine the size of the effect on the general population.

\section{Results}

\subsection{Survey Information Analysis}

The eleven questions in the survey were divided into five sections. Questions 1-3 were used to ascertain the participants' demographic information (see Table 1 above). Question 4 asked how many projects the student reviewed if they reviewed more than one (the assignment only required one). However, because only a few of the respondents reviewed more than one project, this question was not incorporated into the analysis.

Questions 5 and 6 were grouped under the category "Quality of Learning Outcomes." This could be the result of either evaluating a peer's work, or by receiving feedback from a peer. Questions 7 and 8 were grouped under the category "Quality of Feedback." Questions 9 and 10 were grouped under the category "Assignment of Reviewer," to determine their preference concerning how the reviewer was selected. The survey questions and responses in percentages are delineated in Table 2 on the next page.

\subsection{Analysis of Research Questions for the Survey Data}

Research Question 1: Does the peer evaluation process improve the quality of learning outcomes?

There were two possible means by which the learners could improve the quality of their projects. One was through the critical thinking skills they employed while reviewing their peers' projects. The process required them to take the time to systematically read the rubric carefully and realize what they had missed on their own projects by paying more attention to the details as a reviewer. 
Table 2. Descriptive analysis of Q5 - Q10

\begin{tabular}{|c|c|c|}
\hline \multicolumn{2}{|l|}{$\mathrm{SA}^{1}$} & $\mathrm{~N} \quad \mathrm{D}$ \\
\hline
\end{tabular}

\section{Quality of Learning Outcomes}

Q5. Through the process of evaluating another student's project I believe I improved my own skills e.g., my critical thinking skills were improved by the process of evaluating another's work.

Q6. I believe the suggestions my reviewer made helped me improve my own project.

\section{Quality of Feedback}

Q7. Overall, I believe the feedback I received from my peer reviewer(s) was constructive and professional.

Q8. I believe it is possible that my reviewer did not point out things that needed to be changed because

$\begin{array}{lllll}33.9 & 57.1 & 8.9 & 0 & 0\end{array}$
0 they did not want to offend me or were trying to be polite.

\section{Assignment of Reviewer}

Q9. I would prefer to choose the person to evaluate my project.

Q10. I would prefer to have the person evaluating my project assigned because I found it difficult to find/

$\begin{array}{lllll}32.1 & 44.6 & 19.6 & 3.6 & 0\end{array}$

$\begin{array}{lllll}7.1 & 26.8 & 28.6 & 33.9 & 3.6\end{array}$
ask someone.

${ }^{1} \mathrm{SA}=$ Strongly Agree; $\mathrm{A}=$ Agree; $\mathrm{N}=$ Neither Agree nor Disagree; $\mathrm{D}=$ Disagree; $\mathrm{SD}=$ Strongly Disagree

The other was through the feedback received from the student's peer evaluator who pointed out omissions or mistakes they found. Over ninety percent of the learners agreed or strongly agreed that the peer evaluation process improved the quality of their projects. This finding indicates the learners concur that the process of having to evaluate a classmate's project helped them exercise their critical thinking skills as well as pay more attention to the project rubric. Nearly three-quarters of the learners agreed or strongly agreed the feedback they received from their peers about their own project was constructive and helpful.
Research Question 2: Does the method of selection of the peer-evaluator make a difference?

Every semester the researchers found there were usually four to five students who had difficulty finding a classmate to review their projects. When asked if they preferred to choose their own reviewer, or if they would rather have the reviewer who evaluates their project assigned, $37.7 \%$ of the learners preferred to choose their own reviewers to evaluate their projects; while $28.4 \%$ of learners preferred to have their reviewers assigned so they would not have the responsibility of finding someone 
to evaluate their projects. This lead to the question, if their reviewers were assigned, would this have any impact on the results? According to the findings (see Tables 3 and 4), there was no statistically significant difference between the quality of the learning outcomes and the assignment of reviewers. In other words, the quality of the learning outcomes was not affected based on whether the reviewers were self-selected or assigned.

Table 3. Analysis of variance of quality of learning outcomes and assigned reviewers

\begin{tabular}{lccc}
\hline & F & df & Sig. \\
\hline $\begin{array}{l}\text { Project quality improved due to } \\
\text { critical thinking process }\end{array}$ & 2.000 & 4,51 & .109 \\
$\begin{array}{l}\text { Project quality improved due to } \\
\text { constructive feedback }\end{array}$ & .680 & 4,51 & .609 \\
\hline
\end{tabular}

$* p<.05$

Table 4. Analysis of variance of quality of learning outcomes and chosen reviewers

\begin{tabular}{lccc}
\hline & F & df & $p$ \\
\hline $\begin{array}{l}\text { Project quality improved due to critical } \\
\text { thinking process }\end{array}$ & 1.410 & 4,51 & .244 \\
$\begin{array}{l}\text { Project quality improved due to } \\
\text { constructive feedback }\end{array}$ & 2.311 & 4,51 & .070 \\
\hline
\end{tabular}

$* p<.05$

Research Question 3: Does the quality of peer feedback improve learning outcomes?

Of the students completing the survey, over three-quarters agreed or strongly agreed that the feedback they received from their peers was quality feedback that helped to improve their projects. Further, $37.5 \%$ of learners believed, without any reservations, that their peers honestly pointed out areas that needed to be changed in their projects. Table 5 shows there was a statistically significant difference between the quality of learning outcomes and the quality of feedback. This indicated that the quality of the final project was improved if the feedback from peers was accurate and constructive.

Table 5. Analysis of variance of quality of learning outcomes and quality of feedback

\begin{tabular}{lccc}
\hline & F & df & Sig. \\
\hline $\begin{array}{l}\text { Project quality improved due to critical } \\
\text { thinking process }\end{array}$ & 1.027 & 3,52 & .388 \\
$\begin{array}{l}\text { Project quality improved due to } \\
\text { constructive feedback }\end{array}$ & 6.869 & 3,52 & $.001^{*}$ \\
$* p<.05$ & & &
\end{tabular}




\section{Discussion}

There are several important findings that can be gleaned from this study. First, the peer evaluation process facilitates additional opportunities for students to read and apply rubrics, pay more attention to detailed project requirements, and practice critical thinking skills as a result of evaluating each other's projects. More than $90 \%$ of the participants agreed this process played an important role in the enhancement of the quality of their projects. Because peer evaluation was a part of the required assignment, the process compelled the students to spend time carefully reading rubrics and comparing them to the project tasks, something they very likely would not have done had there been no external requirement.

Second, there were differences among student preferences about who reviewed their projects. About one-third of learners preferred to have an assigned reviewer, onethird preferred to choose their own reviewer, and one-third did not have a preference. Even so, the results indicated that how the reviewer was selected did not influence the quality of learning outcomes.

Third, while no difference in how the reviewer was selected was seen, as indicated above, the quality of the feedback provided/ received did matter. The statistical analysis indicated that more than $75 \%$ of the students believed the feedback from their peers was helpful, constructive, and professional.

\section{Conclusion}

Implementing a peer evaluation process in a performance-based Web-enhanced technology course helped students learn, and teach, each other. In this study, over ninety percent of the learners agreed that the peer evaluation process improved the quality of their projects. From this peer evaluation process, the students practiced their critical thinking skills, pointed out areas that needed improvement, and provided this feedback to their peers in a professional manner via Blackboard Discussion threads, as described earlier. Students benefited from the process of peer evaluation not only for the obvious reason - improved quality of their own projects - but they also gained additional new ideas via reviewing their peers' projects. The overall process required the students to pay more attention to the rubric.

In addition, peer evaluation has the potential to reduce teacher workload. Rada, Michailidis, \& Wang (1994) found that instructors benefit from this teaching strategy because the process makes grading much less time-consuming when students have already critiqued each other's work and made certain the criteria on the rubric were met. Thus, saving instructors a substantial amount of time grading is possible when the final project submitted has already met all or most of the requirements delineated in the rubric.

Of course, additional research would be appropriate. Besides replicating the current study, also would be interesting is to attempt to determine the effectiveness of peer evaluation across different disciplines, and/or among other populations such as graduate students or adult learners. In any event, the results of the current study indicate that peer evaluation can be a win-win teaching-learning strategy for everyone involved. 


\section{References}

Ballantyne, R., Hughes, K., \& Mylonas, A. (2002). Developing procedures for implementing peer assessment in large classes using an action research process. Assessment \& Evaluation in Higher Education, 27(5), 427-441.

Brown, S. (1998). Peer Assessment in Practice. Birmingham, AL: Staff and Educational Development Association.

Campbell, D. T., \& Stanley, J. C. (1966). Experimental and quasi-experimental designs for research. Chicago: Rand McNally.

Cheng, W., \& Warren, M. (1997). Having second thoughts: Student perceptions before and after a peer assessment exercise. Studies in Higher Education, 22(2), 233-239.

Cherulnik, P. D. (1983). Behavioral research: Assessing the validity of research findings in psychology. New York: Harper \& Row.

Collis, B., \& Moonen, J. (2001). Flexible learning in a digital world: Experiences and expectations. London: Kogan Page.

Creswell, J. W. (2005). Educational research: Planning, conducting, and evaluating quantitative and qualitative research $\left(2^{\text {nd }}\right.$ ed.). Upper Saddle River, NJ: Pearson Education.

Crooks, T. (1988). The impact of classroom evaluation practices on students. Review of Education Research, 58(4), 438-481.

Falchikov, N., \& Goldfinch, J. (2000). Student peer assessment in higher education: A meta-analysis comparing peer and teacher marks. Review of Educational Research, 70(3), 287-322.

Macpherson, K. (1999). The development of critical thinking skills in undergraduate supervisory management units: Efficacy of student peer assessment. Assessment \& Evaluation in Higher Education, 24(3), 273-284.

Margaryan, A. (2008). Supporting instructors in innovation: A three-component approach. Journal of Workplace Learning, 20(6), 400-415.

Ozogul, G., Olina, Z., \& Sullivan, H. (2008, April). Teacher, self and peer evaluation of lesson plans written by preservice teachers. Educational Technology Research and Development, 56(2), 181-201.

Quarrie, S. (2007). Student peer review as a tool for efficiently achieving subject-specific and generic learning outcomes: Examples in Botany at the faculty of agriculture, University of Belgrade. Higher Education in Europe, 32(2-3), 203 - 212.

Rada, R., Michailidis, A., \& Wang, W. (1994). Collaborative hypermedia in a classroom setting. Journal of Educational Multimedia and Hypermedia, 3(1), 2136.

Root, L. (1987). Faculty evaluation: Reliability of peer assessments of research, teaching, and service. Research in Higher Education, 26(1), 71-84.

Rubin, R. (2006). The academic journal review process as a framework for student developmental. Journal of Management Education, 30(2), 378-398.

Seymour Community Schools (2009). Project Lead the Way Glossary. Seymour Community Schools, Seymour, IN. Retrieved January 19, 2010 from, www. scsc.k12.in.us/technology/pltw/cea glossary.htm

Somervell, H. (1993). Issues in assessment, enterprise and higher education: The case for self-, peer and collaborative assessment. Assessment and Evaluation in Higher Education 18(3) 221-233.

Todd, V., \& Hudson, J.C. (2007, October). Using graded peer evaluation to improve students' writing skills, critical thinking ability, and comprehension of material in a principles of public relations course [Abstract]. Journal of College Teaching \& Learning 4(10), 39-46.

Topping, K. (1998). Peer assessment between 
students in colleges and universities. Review of Educational Research, 68(3), 249-276.

Weeks, K. (1990). The peer review process:

Confidentiality and disclosure. Journal of

Higher Education, 16(2), 198-219.

\section{Contact the Authors}

Ching-Wen Chang, Ph.D.

Missouri State University, USA

E-mail: cchang@missouristate.edu

Cathy J. Pearman, Ph.D.

Missouri State University, USA

E-mail: CathyPearman@MissouriState.edu

Nicholas W. Farha, Ph.D.

Logan University, USA

E-mail: nicholas.farha@logan.edu 


\section{APPENDIX A: Questionnaire for Determining the Effectiveness of Peer Evaluations}

\section{Demographic Data}

1. Please indicate your gender: Female Male

2. Please indicate your age: $\quad 18-22 \quad 23-30 \quad 31-40 \quad 40$ or above

3. Please indicate your status: First Year Sophomore Junior Senior Post-Bachelor Other

4. The assignment only required you to evaluate one of your classmate's PowerPoint Lesson Project. However many students chose to review more than one. How many projects did you review?

[NOTE: Due to extremely low response, this question was excluded from the data analysis.]

Please indicate $(\sqrt{ })$ your level of agreement with the following statements:

SA= Strongly Agree

A=Agree

$\mathrm{N}=$ Neither Agree nor Disagree

$\mathrm{D}=$ Disagree

$\mathrm{SD}=$ Strongly Disagree

\begin{tabular}{|c|c|c|c|c|c|}
\hline Questions & SA & $\mathbf{A}$ & $\mathbf{N}$ & D & SD \\
\hline $\begin{array}{l}\text { Quality of Learning Outcomes } \\
\text { 5. Through the process of evaluating another student's project I } \\
\text { believe I improved my own skills e.g., my critical thinking skills } \\
\text { were improved by the process of evaluating another's work. }\end{array}$ & & & & & \\
\hline $\begin{array}{l}\text { 6. I believe the suggestions my reviewer made helped me improve } \\
\text { my own project. }\end{array}$ & & & & & \\
\hline $\begin{array}{l}\text { Quality of Feedback } \\
\text { 7. Overall, I believe the feedback I received from my peer reviewer(s) } \\
\text { was constructive and professional. }\end{array}$ & & & & & \\
\hline $\begin{array}{l}\text { 8. I believe it is possible that my reviewer did not point out things } \\
\text { that needed to be changed because they did not want to offend } \\
\text { me or were trying to be polite. }\end{array}$ & & & & & \\
\hline $\begin{array}{l}\text { Assignment of Reviewer } \\
\text { 9. I would prefer to choose the person to evaluate my project. }\end{array}$ & & & & & \\
\hline $\begin{array}{l}\text { 10. I would prefer to have the person evaluating my project be } \\
\text { assigned because I found it difficult to find/ask someone. }\end{array}$ & & & & & \\
\hline
\end{tabular}

\section{Additional Information}

11. Please provide any additional comments that might help the instructor improve the peer evaluation process for this course:

[NOTE: The responses to this question were all anecdotal in nature and thus were not appropriate for the analysis.] 


\section{APPENDIX B: Peer Evaluation Rubric}

Instructions: As part of the process for the PowerPoint Project, (1) you are required to do a peer evaluation for at least one of your classmates. (2) You are also required to obtain a peer review from a classmate.

On the designated date, post your own CBI Project to the Peer Review Forum in the Discussion Board area. Ask specific questions about what you would like them to review as well as having them use the rubric.

Then read at least one of your classmate's projects and give them constructive feedback following the guidelines below. Provide any additional information that would be helpful to the person you are reviewing. This is an opportunity to practice language, communication and critical analysis skills when reviewing another's work.

\section{Criteria:}

\begin{tabular}{|l|c|}
\hline \multicolumn{1}{|c|}{ Criteria } & Points \\
\hline Peer Review is at least 150 words. & $\mathbf{4}$ \\
\hline All questions from person posting are answered. & $\mathbf{2}$ \\
\hline $\begin{array}{l}\text { Manner and language are professional reflecting best practices and } \\
\text { attitudes befitting a teacher reviewer. }\end{array}$ & $\mathbf{2}$ \\
\hline Feedback posted by designated date and time. (See Syllabus) & $\mathbf{2}$ \\
\hline & $\mathbf{1 0}$ \\
\hline
\end{tabular}




\section{APPENDIX C: Computer-Based Instruction Rubric}

Name

Section

Requirements: This artifact should serve as a tutorial to teach a concept to your students. It should be developed using PowerPoint and should offer a non-linear as well as linear design (Students travel from a TOC and then sequentially through each instructional section.) The artifact should meet the requirements in this assessment tool. The PowerPoint will contain 3 main sections: instructional content, Scaffolding Tool to expand learning, and a quiz to reinforce learning.

\begin{tabular}{|c|c|c|c|}
\hline Description & Criteria & $\begin{array}{l}\text { Point } \\
\text { Value }\end{array}$ & Pts. \\
\hline \multirow[t]{6}{*}{ Story map } & $\begin{array}{l}\text { - Story map must be done in Inspiration or other web- } \\
\text { based tools. }\end{array}$ & 1 & \\
\hline & - Story map indicates non-linear structure. & 2 & \\
\hline & - $\quad$ Each bubble/slide must be labeled. & 1 & \\
\hline & - Use graphics and/or default bubbles. & 1 & \\
\hline & - Change bubble default color. & 1 & \\
\hline & - Turn in Story concept map to Blackboard & 1 & \\
\hline \multirow[t]{7}{*}{ Content } & - Reading level of content is appropriate for grade level. & 4 & \\
\hline & $\begin{array}{l}\text { - An embedded document scaffolds the instruction } \\
\text { (Provide directions and submission guidelines.) }\end{array}$ & 5 & \\
\hline & $\begin{array}{l}\text { - Interactive Quiz covers major concepts in the tutorial, } \\
\text { presented in multiple choice format with immediate } \\
\text { feedback to the student (at least } 3 \text { questions) }\end{array}$ & 3 & \\
\hline & $\begin{array}{l}\text { - Audio file (Personal recording) or video file is } \\
\text { embedded. }\end{array}$ & 2 & \\
\hline & $\begin{array}{l}\text { - The difficulty level of task/product is appropriate for the } \\
\text { grade level. }\end{array}$ & 1 & \\
\hline & - Add 3 hypertext links to relative websites. & 3 & \\
\hline & $\begin{array}{l}\text { - Visual/graphics used to motivate and illustrate (in } \\
\text { addition to the template design). }\end{array}$ & 1 & \\
\hline
\end{tabular}




\begin{tabular}{|c|c|c|}
\hline \multirow[t]{6}{*}{ Structure } & $\begin{array}{l}\text { - Title slide provides a descriptive title, the designer's } \\
\text { name, grade/subject, date, etc. }\end{array}$ & 1 \\
\hline & $\begin{array}{l}\text { Slide } 2 \text { states } \\
\quad \begin{array}{l}\text { the purpose of this CBI to the student in } \\
\text { conversational language. } \\
>\quad \text { the learning outcomes of this CBI. } \\
>\quad \text { how CBI has been designed to meet diversity } \\
\text { requirement i.e. large text, audio, etc. }\end{array}\end{array}$ & 3 \\
\hline & $\begin{array}{l}\text { - Slide } 3 \text { (Directions) explains the navigation system } \\
\text { (icons) to the student. }\end{array}$ & 1 \\
\hline & $\begin{array}{l}\text { - Slide } 4 \text { (Main Menu/Table of Content) serves as an } \\
\text { interactive menu to each major sections of the content. }\end{array}$ & 1 \\
\hline & $\begin{array}{l}\text { - Summary/Conclusion slide restates the most important } \\
\text { points learned in the PowerPoint lesson. }\end{array}$ & 1 \\
\hline & $\begin{array}{l}\text { Resources slide presents the names and web addresses } \\
\text { for at least } 2 \text { resources that were used. }\end{array}$ & 2 \\
\hline \multirow[t]{10}{*}{$\begin{array}{l}\text { Design \& } \\
\text { Layout }\end{array}$} & $\begin{array}{l}\text { Formatting (e.g. font type \& size, color, emphasis) } \\
\text { follows visual literacy guidelines. }\end{array}$ & 2 \\
\hline & $\begin{array}{l}\text { - All graphics are sized and positioned on the slide to } \\
\text { create balance and are clear. }\end{array}$ & 1 \\
\hline & $\begin{array}{l}\text { - Navigation buttons are labeled and active; place on } \\
\text { Master Slide. }\end{array}$ & 2 \\
\hline & $\begin{array}{l}\text { Each slide has a title. Be consistent in size, font, color, } \\
\text { and placement. }\end{array}$ & 1 \\
\hline & $\begin{array}{l}\text { - Slide layout and design templates enhance the delivery } \\
\text { of the information. }\end{array}$ & 1 \\
\hline & $\begin{array}{l}\text { Text is not crowded, consistent in type and sized. Color } \\
\text { contrast with background. Only hyperlinks will appear } \\
\text { underlined. }\end{array}$ & 1 \\
\hline & - Custom transitions are consistent. (Change default.) & 1 \\
\hline & $\begin{array}{l}\text { - Custom animations/effects not too fast or slow and allow } \\
\text { enough viewing time; limited in number. }\end{array}$ & 1 \\
\hline & - Minimum of 20 slides. & 1 \\
\hline & $\begin{array}{l}\text { - The content is well articulated with no grammar or } \\
\text { spelling errors, and is instructional. }\end{array}$ & 1 \\
\hline
\end{tabular}




\begin{tabular}{|c|c|c|}
\hline \multirow{4}{*}{$\begin{array}{l}\text { Peer } \\
\text { Evaluation \& } \\
\text { Submission }\end{array}$} & $\begin{array}{l}\text { - Peer Evaluation instructions are provided on } \\
\text { Blackboard. Please follow the instructions. }\end{array}$ & 10 \\
\hline & $\begin{array}{l}\text { - Saved as a PowerPoint Presentation (.ppt) and } \\
\text { PowerPoint Show (.pps) }\end{array}$ & 1 \\
\hline & - Final CBI file submit as instructed. & 1 \\
\hline & - Project is set in Kiosk mode. & 1 \\
\hline Total & & 60 \\
\hline
\end{tabular}

